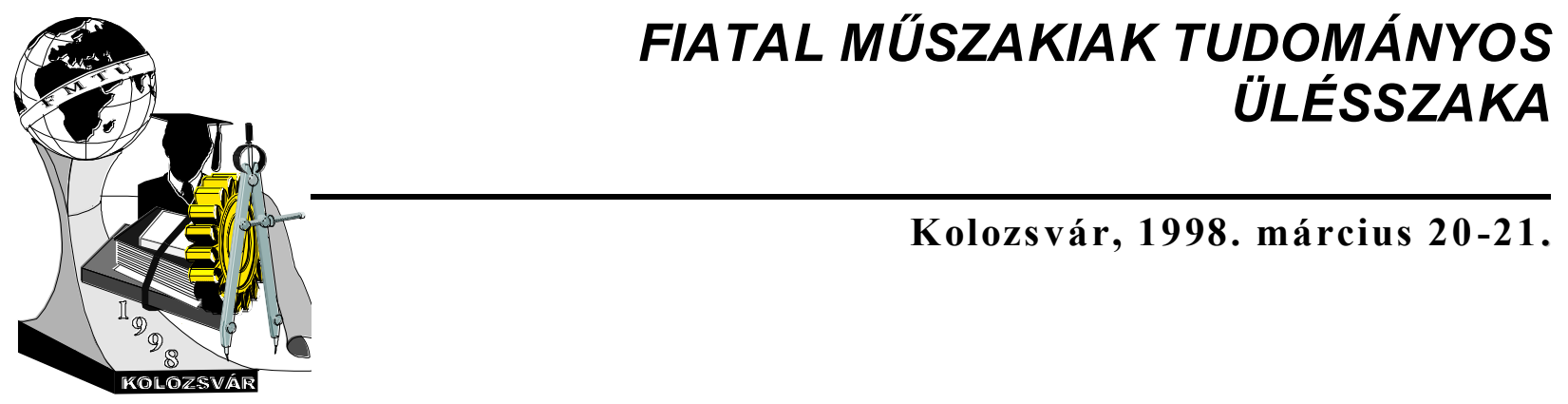

\title{
A hajtómúgyártás költségének becslése mesterséges intelligencia módszerek alkalmazásával
}

\author{
Kovács Józs ef
}

The object of the work is the approximate cost estimation for driving-gear-manufacturing in the early stage of production planning by utilizing artificial intelligence method. During the preliminary production planning one of the tasks to solve is the estimation of production time and cost to provide the necessary information for the enterprise management and the production management. The system developed in this work can be applied for early cost estimate of overall products and the subassemblies too. The basis of the estimation is the earlier planning cases, the engineering experience and the similarity of the products. Cost estimation uses case-based retrieval techniques to help the user in making decisions. The system has on one hand an efficient database handler and on the other hand a component which able to learn. The work gives multispeed-driving gears as an example to demonstrate the system.

\section{Becsült költség és normaadatok képzése}

A módszer alapelve, hogy a becslést két különböző szinten kell elvégezni:

- a gyártmány egészét vizsgálva

- a gyártmányt részegységekre, un. modulokra bontani (illetve azokból felépíteni), majd ezt követően az adott modulok gyártását és azok "egyesítését" (szerelés) vizsgálva

Ez a megközelítés azért indokolt, mert adott esetekben elegendő csak egy "durva" becslést adni, amelyhez alacsony szintủ hasonlóság is elég máskor viszont szükséges egy mélyebb szintű, részletesebb becslés. A két szintet indokolja még az is, hogy a hasonlóság már magasabb szinten is teljesülhet, mert a gyártmány szerepel az adatbázisban. A megoldási mód természetesen különböző a két szinten (1.ábra).

\section{Gyártmány szintü hasonlóság}

A gyártmányszintủ megközelítésnél a gyártmány egészére vonatkozó információk lekérdezése történik. Ezek olyan adatok, amelyek a gyártmány típusának és méretének leírására szolgálnak és amelyek alapján a konkrét gyártmány beazonosítható. A típushoz tartozó gyártmányok között kell a hasonlósági keresést lefolytatni. A keresés eredménye képpen a „legközelebbi” gyártmány adatait és a hasonlóság mértékét kapjuk. Ha a hasonlóság mértéke nem kielégítő, a módszer felkínálja a részegység szintủ hasonlóság alapján történő keresést. 


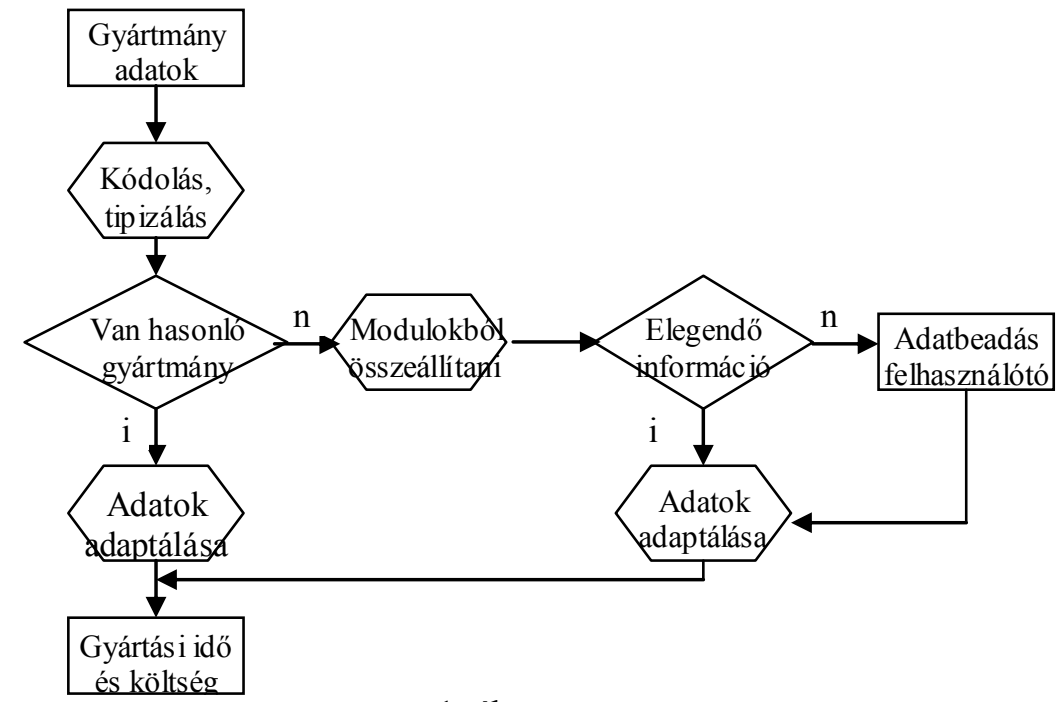

1. ábra

\section{Részegység szintü hasonlóság}

Ha a gyártmány szintü hasonlóság alapján történő keresés eredménye nem kielégítő, részegység szinten kell a gyártmányt vizsgálni. Mivel a konstrukciós tervek különböző formátumúak (szabadkézi vázlat, hagyományos müszaki rajz, CAD modell) lehetnek, célszerü egy egységes, modulokból építkező modellezési eljárást kidolgozni, amely a következő tulajdonságokkal rendelkezik:

- minden gyártmány felépíthető legyen a modulok alapján

- egyszerü építkezés, kezelés a felhasználó számára

- technológiai és geometriai információk egyaránt leírhatóak legyenek

- szimbolikus követés lehetősége

- számolni lehessen vele

Ezen a szinten a felhasználó modulokból felépíti a konkrét gyártmányt és megadja a modulokra jellemző alapinformációkat. Ezt követően elöször a modul szintü hasonlóság keresése következik (a gyártmányszintü keresés már az első lépésben megtörtént). A modulok összeépítésével, "egyesítésével” a szerelést lehet modellezni, ahol a szerelési költség és idő becslésére szintén a korábbi esetek szolgálnak alapul. Amennyiben a keresés eredménye nem kielégítő, a felhasználónak lehetősége van költség- és időadatok beadására.

A költség és normadatok becslése a konstrukciós tervezéstől, a vállalatirányítástól, a termelésirányítástól és a készletgazdálkodástól kapott információkra épül.

1. A gyártmányról kapott információk:

- teljes vagy vázlatos konstrukciós terv

-gyártandó darabszám

2. A gyártási környezetre jellemző információk:

-technológiai teljesítőképesség

-gazdasági információk (pl.:rezsi, normaidők)

-anyag- és erőforrás információk 
A gyártási környezetre jellemző információk alapján gyártási környezet adatbázisa építhető fel, ami a vállalat profilját mutatva az általános, gyártmányfüggetlen információkra épül és a vállalat egészére jellemző. A szakértői tudás és a hasonlítási, következtetési szabályok alapján meg kell alkotni egy keretrendszert, amely a keresés és a következtetés folyamatát vezérli, koordinálja. A becslés alpjául a korábbi esetek szolgálnak, amelyeket adatbázisokban kell tárolni. Megkülönböztetünk gyártmánycsaládés modul- (részegység) adatbázisokat. Azért kell a modulokat elkülönített adatbázisban tárolni, mert adott modulok különböző gyártmánycsaládokba is beépülhetnek (pl.: tengely szivattyúba és hajtómübe egyaránt (2.ábra).

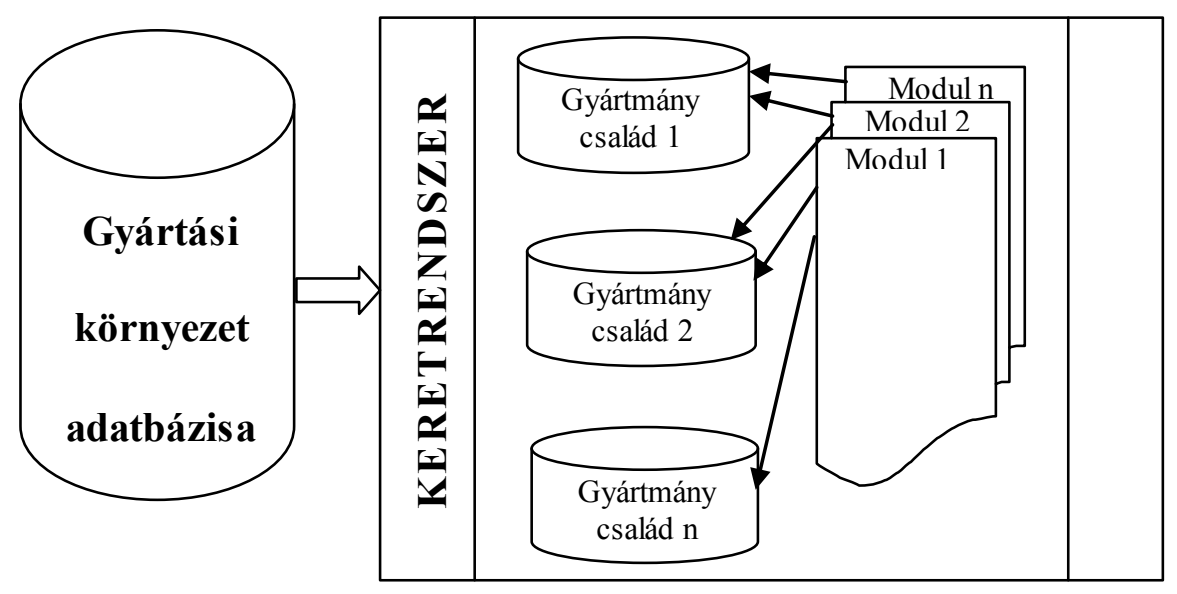

2. ábra

\section{A gyártmány: Fogaskerekes hajtómü}

A módszer bemutatására a gépipari gyártmányok közül a fogaskerekes hajtómúveket hozzuk példának. Azért erre a gyártmánycsaládra esett a választás, mert a hajtómű jól struktúrált, összetett, váltazatos kialakítású, de egyben jól tipizálható gyártmány. Az egyszerüség kedvéért a gyártmánycsaládon belül az alábbi hajtómü típusokat vizsgáljuk:

- Egyfokozatú, hengereskerekü hajtómü (E)

- Kétfokozatú, hengereskerekü (K) és kúp-hengeres kerekü (KK) hajtómü

- Háromfokozatú, hengereskerekü (H) és kúp-hengeres kerekü $(\mathrm{KH})$ hajtómü

\section{Gyártmány szintü megközelités}

Az új gyártmányról a következő adatokat kell megadnia a felhasználónak:

- hajtómü típusa

- befoglaló méretek

- kimenő nyomaték

- utólsó tengelytáv

- gyártandó darabszám

- különleges előírás (üzemeltetési körülmény) 
A gyártmány adatainak megadása után a kód alapján a hasonló típusú hajtómüvek között keresünk hasonlót. Ha a hasonlóság mértéke nem kielégitő a következő lépéseken keresztül elvégzünk egy durva becslést:

1. a hajtómütípusra jellemző hajtómüsürüség (súly/befoglaló térfogat) és a befoglaló méretekből kiszámolt térfogat alapján meghatározzuk a gyártandó hajtómü közelítő súlyát

2. a hajtómü típus, a gyártandó darabszám és az egységnyi tengelytávon átvitt nyomaték alapján adaptáljuk a típusra jellemző egységnyi súlyra jutó gyártási költség és idő értékeket, majd ezekkel szorozzuk a becsült hajtómű súlyt

\section{Részegység szintü megközelítés}

Az új gyártmányt a rendelkezésre álló részegységekből, modulokból felépíti a felhasználó és megadja a modul leírásához szükséges adatokat.

A hajtóművek részei: hajtóműház, csapágyfedél, fogazott alkatrész, tengely, csapágy, tömítés, kiegészítő elemek, kötö-, illesztőelemek

Ezen részekből a jelentősebb költséghordozók a következők: hajtóműház, fogazott alkatrész, tengely, csapágy

Megemlítendő, hogy a hajtómüveknél a részegység és az alkatrész szint nem különül el olyan nagy mértékben, mint például az autóknál, ahol a részegységek (motor, ajtó, stb) valóban egységek, amelyek alkatrészekből illetve további részegységekből épülnek fel. Ezt követően a modul-adatbázisból keresünk hasonló modulokat és megvizsgáljuk, hogy az adott modul hasonlósága kielégítő-e és van-e elég adat a gyártási költségre és időre vonatkozóan. Ha igen, kiolvassuk és adaptáljuk az adott esetre. Ha nincs elegendő adat, felkínáljuk a felhasználónak azok megadását. A modulok egymásra épülése, kapcsolódása alapján a gyártmányadatbázis régi eseteinek felhasználásával becsült értékeket adunk a szerelésre vonatkozóan. Ezt követően összegezzük a modulok előállitási és az un. Egyesítési, szerelési idejét és költségét.

\section{Összegzés}

Az említett módszer lehetővé teszi a korai költség- és időbecsléshez szükséges mérnöki tudás és tapsztalat formalizált, számítógépes megközelítését illetve segítését. A becslés különböző, egyre mélyebb szinten történő elvégzése következtében a becslés pontossága egyre nő, hiszen minnél részletesebben vizsgáljuk a gyártmányt a becslés hibája annál kissebb a teljes gyártmányra vonatkozóan.

Kovács József / okl. gépészmérnök doktorandusz hallgató

Budapesti Müszaki Egyetem Gépgyártástechnológia Tanszék / H-1521 Budapest, Pf. 91.

Tel:(36 1) 463-2515 Fax:(36 1) 463-3176 / E-mail: KOVACSJ@NEXT-1B.MANUF.BME.HU 